\title{
Fiebre de origen desconocido y linfadenopatia en contexto de lupus: presentación de un caso clínico de enfermedad de Castleman
}

\section{Fever of unknown origin and lymphadenopathy in the context of lupus: presentation of a clinical case of Castleman disease}

\author{
Mercedes Cecilia Córdoba ${ }^{1}$, José Sironi ${ }^{1}$, Juan Trakal ${ }^{2}$, Luciano Salvano ${ }^{3}$, Apaz María ${ }^{1}$, Marcelo Sánchez \\ Freytes ${ }^{1}$.

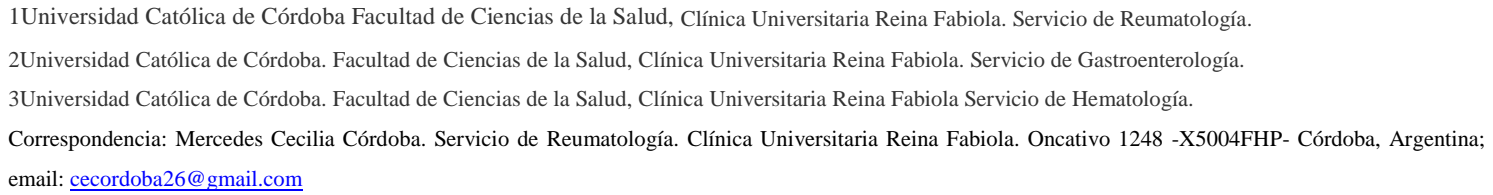

\section{Introducción}

La linfadenopatía ocurre en aproximadamente el $60 \%$ de los pacientes con lupus eritematoso sistémico (LES) durante la evolución de la enfermedad. Estas lesiones de ganglios linfáticos son caracterizadas por hiperplasia folicular, necrosis coagulativa, cuerpos de hematoxilina y deposición de ADN dentro de los vasos. Como consecuencia, se subestima al examen histopatológico de los ganglios linfáticos en LES ${ }^{1}$. Se han notificado casos de linfadenopatía de LES con morfología de enfermedad de Castleman (EC), que se descubre con el fin de excluir el linfoma maligno. La EC es un trastorno de linfoproliferación atípica que puede presentarse con o sin síntomas sistémicos ${ }^{2-3}$. Histológicamente, la EC se clasifica como variante hialino-vascular, de células plasmáticas o mixtas. La histología hialino-vascular representa la mayoría de casos de EC unicéntrico (ECU) y el tipo de célula plasmática caracteriza más a la EC multricéntrico (ECM). Se ha demostrado que la ECM tiene asociación con varias enfermedades autoinmunes ${ }^{4-5}$. En este informe, presentamos una paciente con LES y enfermedad de Crohn con fiebre de origen desconocido (FOD) y linfadenopatías con EMC asociado a infección por virus herpes 8 (HHV-8).

\section{Objetivo}

Destacar a la EC como una causa de FOD y linfadenopatías en LES en tratamiento inmunosupresor.

\section{Material y método}

Se analizó el caso de una mujer con enfermedad de Crohn y LES en tratamiento inmunosupresor que presentó FOD asociado a linfadenopatías.

\section{Resultados}

Mujer de 37 años con antecedentes de enfermedad de Crohn, LES (anti-DNA 1/40, ANA 1/320 patrón moteado fino, consumo de complemento, alopecia difusa, leucopenia) e hipotiroidismo en tratamiento con adalimumab $40 \mathrm{mg}$, azatioprina $100 \mathrm{mg}$ día, hidroxicloroquina $200 \mathrm{mg}$ dos veces 
día, meprednisona $4 \mathrm{mg}$ día, levotiroxina $100 \mathrm{mcg}$ día.

Presentó fiebre de $38-39{ }^{\circ} \mathrm{C}$, vespertina, intermitente de 2 registros diarios acompañada de sudoración nocturna, leve pérdida de peso, artromialgias, alopecia difusa. Al examen palidez, temperatura de $38.6{ }^{\circ} \mathrm{C}$, FC 104 lpm, presión arterial de 100/60 $\mathrm{mmHg}$, frecuencia respiratoria de 18 por minuto, con una saturación de oxígeno aire ambiente del $98 \%$, alopecia difusa, reticulado de tipo vasculítico en manos, con adenopatías móviles, renitentes, no dolorosas, de menos de 1 $\mathrm{cm}$, en región posterior y laterocervical, supraclavicular y axilar bilaterales (la de mayor tamaño en vértice axilar izquierdo de $2 \mathrm{~cm}$ ). Resto del examen sin alteraciones. En el laboratorio se constata anemia inflamatoria ( $\mathrm{Hb} \quad 7.7$ gr\%), leucopenia con neutropenia leve y franca linfopenia, elevación leve de eritrosedimentación $22 \mathrm{~mm}$ y proteína C reactiva de $20 \mathrm{mg} / \mathrm{l}$, hipoalbuminemia, hipocomplementemia, ANA 1/5120 patrón moteado fino, anti DNA 1/40. La funcione renal, hepática y el sedimento urinario fueron normales.

Se inicia tratamiento antibiótico con ampicilina sulbactam, suspendiendo adalimumab y azatioprina. Se solicitan hemocultivos, urocultivo, procalcitonina, PPD, serologías para HIV, Hepatitis B y C, VDRL, chlamydia, VEB, influenza $\mathrm{A}-\mathrm{B}$ que resultaron negativos, sólo destaca citomegalovirus con IgM positiva, pero con antígeno temprano negativo. Tomografía de tórax adenopatías axilares bilaterales; la mayor en axila izquierda de 21 x $12 \mathrm{~mm}$; resto sin alteraciones. TAC de abdomen-pelvis engrosamiento difuso del íleon terminal, con espesor máximo de $8 \mathrm{~mm}$, reducción de la luz, ganglios mesentéricos y retroperitoneales menores de $10 \mathrm{~mm}$.

Basado en el examen físico y pruebas de laboratorio se diagnostica actividad de LES y se decide la extracción quirúrgica de ganglio linfático axilar izquierdo, que mostró hiperplasia folicular en corteza y médula, centros germinales prominentes, en algunos de los folículos vasos con hialinización, en áreas interfoliculares plasmocitos con glóbulos citoplasmáticos eosinófilos.

Inmunohistoquímica positiva para $\mathrm{HHV}-8$, lo que indica diagnóstico de ECM asociado a HHV-8. Se inicia terapia con prednisona $40 \mathrm{mg}$ por 10 días con disminución de linfadenopatías.

\section{Conclusiones}

Los hallazgos histopatológicos de la EC en pacientes con LES son raramente reportados.

La ECM se presenta como una enfermedad sistémica con adenomegalias diseminadas, síntomas constitucionales, anomalías autoinmunes, infecciones recurrentes y de laboratorio con signos y síntomas superpuestos con enfermedades autoinmunes ${ }^{6-7}$.

En el diagnóstico diferencial, además de las linfadenopatías del LES y las neoplasias malignas hematológicas, se deben tener en cuenta otras enfermedades como tuberculosis, sarcoidosis, metástasis y Kikuchi-Fujimoto ${ }^{8}$. El tratamiento incluye dosis altas de esteroides, radioterapia y quimioterapia sistémica de acuerdo con los diferentes tipos de EC. Desde una perspectiva terapéutica, destacamos en la posibilidad de morfología de EC en pacientes con linfadenopatías por LES.

\section{Introduction}

Lymphadenopathy occurs in approximately $60 \%$ of patients with systemic lupus erythematosus (SLE) during the course of the disease. These lymph node lesions are characterized by follicular hyperplasia, coagulative necrosis, hematoxylin bodies and DNA deposition within the vessels. As a consequence, the histopathological examination of the lymph nodes in SLE is underestimated ${ }^{1}$. There have been reports of SLE lymphadenopathy with Castleman's disease (CD) morphology, which is discovered in order to exclude malignant lymphoma. CD is an atypical lymphoproliferative disorder that can occur with or without systemic symptoms ${ }^{2-3}$. Histologically, CD is classified as an hyaline-vascular variant, plasmatic cells or mixed forms ${ }^{4}$. Hyaline-vascular histology represents the majority of cases of unicentric CD (UCD) and the type of plasmatic cell characterizes more to the multicentric CD (MCD). It has been shown that MCD is associated with various autoimmune diseases $^{5-6}$. In this report, we present a patient with SLE and Crohn's disease with fever of unknown origin (FUO) and lymphadenopathy with MCD associated with herpes virus infection 8 (HHV-8).

\section{Objective}

Highlight $\mathrm{CD}$ as a cause of FUO and lymphadenopathy in SLE in immunosuppressive treatment.

\section{Material and method}

We analyzed the case of a woman with a history of Crohn's disease and SLE in immunosuppressive treatment who presented FUO associated with lymphadenopathy. 


\section{Results}

37-year-old woman with a history of Crohn's disease, SLE (anti-DNA 1/40, ANA 1/320 fine mottled pattern, complement consumption, diffuse alopecia, leukopenia) and hypothyroidism on treatment with adalimumab $40 \mathrm{mg}$, azathioprine $100 \mathrm{mg}$ day, hydroxychloroquine $200 \mathrm{mg}$ twice daily, meprednisone $4 \mathrm{mg}$ day, levothyroxine 100 mcg day.

She presented afternoon fever of $38-39^{\circ} \mathrm{C}$, intermittent of 2 daily records accompanied by night sweats, mild weight loss, arthromyalgia, diffuse alopecia. Upon pallor examination, temperature of $38.6^{\circ} \mathrm{C}$, HR $104 \mathrm{bpm}$, blood pressure of $100 / 60 \mathrm{mmHg}$, respiratory rate of 18 per minute, with ambient air oxygen saturation of $98 \%$, diffuse alopecia, vasculitic-type reticulate on hands, with mobile adenopathies, renitent, not painful, less than $1 \mathrm{~cm}$, in posterior region and laterocervical, supraclavicular and axillary bilateral (the largest in left axillary vertex of $2 \mathrm{~cm}$ ). Rest of the exam without alterations. In the laboratory, inflammatory anemia ( $\mathrm{Hb} 7.7 \mathrm{gr} \%$ ), leukopenia with mild neutropenia and frank lymphopenia, mild elevation of $22 \mathrm{~mm}$ erythrosedimentation and C-reactive protein of 20 mg / 1, hypoalbuminemia, hypocomplementemia, ANA 1/5120 fine mottled pattern, anti DNA 1/40. Renal, hepatic function and urinary sediment were normal.

Antibiotic treatment is started with ampicillin sulbactam, suspending adalimumab and azathioprine. Blood cultures, urine cultures, procalcitonin, PPD, serology for HIV, Hepatitis B and C, VDRL, chlamydia, EBV, influenza A-B that were negative, only highlight cytomegalovirus with positive IgM, but with negative early antigen. Chest tomography: bilateral axillary adenopathies; the largest in the left axilla of $21 \times 12 \mathrm{~mm}$; rest without alterations. TAC abdomen-pelvis diffuse thickening of the terminal ileum, with a maximum thickness of $8 \mathrm{~mm}$, reduction of light, mesenteric and retroperitoneal nodes smaller than $10 \mathrm{~mm}$.

Based on the physical examination and laboratory tests, SLE activity was diagnosed and surgical removal of the left axillary lymph node, which showed follicular hyperplasia in the cortex and medulla, prominent germinal centers, in some of the hyalinizing vessels follicles, was decided. interfollicular plasmocytes with eosinophilic cytoplasmic globules. Positive immunohistochemistry for $\mathrm{HHV}-8$, indicating diagnosis of ECM associated with HHV-8. Therapy was started with prednisone $40 \mathrm{mg}$ for 10 days with a decrease in lymphadenopathy.

\section{Conclusions}

The histopathological findings of $\mathrm{CD}$ in patients with SLE are rarely reported. MCD presents as a systemic disease with disseminated lymphadenopathy, constitutional symptoms, autoimmune abnormalities, recurrent and laboratory infections with signs and symptoms superimposed with autoimmune diseases.

In the differential diagnosis, in addition to the lymphadenopathies of SLE and hematological malignancies, other diseases such as tuberculosis, sarcoidosis, metastasis and Kikuchi-Fujimoto disease must be taken into account. The treatment includes high doses of steroids, radiotherapy and systemic chemotherapy according to the different types of CD. From a therapeutic perspective, we highlight the possibility of CD morphology in patients with lymphadenopathy due to SLE.

\section{Bibliografía}

1. Jing-yan X, Xi-yuan C, Feng Xu, Yan Yang, Hui-ying W, Jing Xue, A case report of systemic lupus erythematosus combined with Castleman's disease and literature review, Rheumatol Int (2012) 32:21892193.

2. Gohlke F, Marker-Hermann E, Kanzler S et al (1997) Autoimmune findings resembling connective tissue disease in a patient with Castleman's disease. Clin Rheumatol 16:87-92

3. Simko R, Nagy K, Lombay B et al (2000) Multiventric castleman disease and systemic lupus erythematosus phenotype in a boy with Klinefelter syndrome: long-term disease stabilization with interferon therapy. J Hediatr Oncol 22:180-183

4. Ben-Chetrit E, Flusser D, Okon E, Ackerman Z, RubinowA (1989) Multicentric Castleman's disease associated with rheumatoid arthritis; A possible role of hepatitis B antigen. Ann Rheum Dis 48: 326-330

5. Couch WD (1980) Giant lymph node hyperplasia associated with thrombotic thrombocytopenic purpura. Am J Clin Pathol 74: 340-344

6. Kojima M, Nakamura S, Itoh H et al (1997) Systemic lupus erythematosus lymphadenopathy presenting with histopathologic features of Castleman' 
Córdoba C, Sirono J, Trakal J, Salvano L, Apaz M, Sánchez Freytes M. Fiebre de origen desconocido y linfadenopatia en contexto de lupus: presentación de un caso clínico de enfermedad de castleman.

disease: a clinicopathologic study of five cases. Pathol Res Pract 193:565-571

7. Herrada J, Cabanillas F, Rice L et al (1998) The clinical behavior of localized and multicentric Castleman disease. Ann Intern Med 128:657-662

8. Bowne WB, Lewis JJ, Filippa DA et al (1999) The management of unicentric and multicentric Castleman's disease: a report of 16 cases and a review of the literature. Cancer 85:706-717.

\section{Palabras claves}

LES, LINFADENOPATÍA, FIEBRE DE ORIGEN

DESCONOCIDO, ENFERMEDAD DE

CASTLEMAN.

\section{Keywords}

SLE, LYMPHADENOPATHY, FEVER OF UNKNOWN ORIGIN, CASTLEMAN'S

DISEASE.

\section{(c) (1) Q) \\ BY NC SA}

